\title{
Mitotane reduces human and mouse ACTH-secreting pituitary cell viability and function
}

\author{
Erica Gentilin ${ }^{1,2}$, Federico Tagliati ${ }^{1}$, Massimo Terzolo ${ }^{3}$, Matteo Zoli ${ }^{4}$, \\ Marcello Lapparelli ${ }^{5}$, Mariella Minoia ${ }^{1}$, Maria Rosaria Ambrosio', Ettore C degli Uberti ${ }^{1,2}$ \\ and Maria Chiara Zatelli, \\ ${ }^{1}$ Section of Endocrinology, Department of Medical Sciences, University of Ferrara, Via Savonarola 9, \\ 44100 Ferrara, Italy \\ ${ }^{2}$ Laboratorio in Rete del Tecnopolo Tecnologie delle Terapie Avanzate (LTTA), University of Ferrara, Ferrara, Italy \\ ${ }^{3}$ Division of Internal Medicine I, Department of Clinical and Biological Sciences, Faculty of Medicine San Luigi \\ Gonzaga, University of Turin, Turin, Orbassano (TO), Italy \\ ${ }^{4}$ Department of Neurosurgery, Ospedale Bellaria, Bologna, Italy \\ ${ }^{5}$ Neurosurgery Unit, Ferrara Hospital, Ferrara, Italy
}

Correspondence should be addressed to M C Zatelli

Email

dut@unife.it

\begin{abstract}
Medical therapy for Cushing's disease (CD) is currently based on agents mainly targeting adrenocortical function. Lately, pituitary-directed drugs have been developed, with limited efficacy. Mitotane, a potent adrenolytic drug, has been recently investigated for the treatment of $C D$, but the direct pituitary effects have not been clarified so far. The aim of our study was to investigate whether mitotane may affect corticotroph function and cell survival in the mouse pituitary cell line AtT20/D16v-F2 and in the primary cultures of human ACTHsecreting pituitary adenomas, as an in vitro model of pituitary corticotrophs. We found that in the AtT20/D16v-F2 cell line and in primary cultures, mitotane reduces cell viability by inducing caspase-mediated apoptosis and reduces ACTH secretion. In the AtT20/D16v-F2 cell line, mitotane reduces Pomc expression and blocks the stimulatory effects of corticotropinreleasing hormone on cell viability, ACTH secretion, and Pomc expression. These effects were apparent at mitotane doses greater than those usually necessary for reducing cortisol secretion in Cushing's syndrome, but still in the therapeutic window for adrenocortical carcinoma treatment. In conclusion, our results demonstrate that mitotane affects cell viability and function of human and mouse ACTH-secreting pituitary adenoma cells. These data indicate that mitotane could have direct pituitary effects on corticotroph cells.
\end{abstract}
Key Words
- Cushing's disease
- mitotane
- corticotropin-releasing hormone
- pituitary function
- POMC

Journal of Endocrinology (2013) 218, 275-285

\section{Introduction}

Cushing's disease (CD), characterized by hypercortisolism due to excessive secretion of ACTH by the pituitary gland, is a rare disease with an incidence between 0.7 and 2.4 cases per million per year (Patil et al. 2008). Currently, the treatment of choice for patients with CD is surgery, but late recurrence occurs in 5-20\% of patients (Atkinson et al. 2005). Although a variety of treatments are available, pituitary irradiation is a good option for aggressive $\mathrm{CD}$ that fails to respond to surgery, invades the cavernous sinus, or relapses following an initial remission, but the treatment is associated with important side effects (Mahmoud-Ahmed \& Suh 2002). Laparoscopic bilateral adrenalectomy can be safely and effectively employed to treat $\mathrm{CD}$ but needs permanent glucocorticoid 
supplementation (Porpiglia et al. 2004). Several medical therapies, including steroidogenic inhibitors, centrally acting agents, and glucocorticoid receptor inhibitors, are currently being used or investigated as a potential treatment for CD (Biller et al. 2008, Feelders et al. 2010), but their efficacy was found to be unpredictable (Tritos \& Biller 2012). Recently, a retrospective study has highlighted the efficacy of mitotane therapy in CD treatment (Baudry et al. 2012). Mitotane (o, $p^{\prime}$-DDD), a derivative of the insecticide dichlorodiphenyltrichloroethane, has been widely used for treatment of advanced (unresectable, metastatic, or relapsed) adrenocortical carcinoma (ACC; Bergenstal et al. 1960, Young et al. 1973, Hogan et al. 1978, Lughezzani et al. 2010) and is increasingly used in adjuvant settings (Fassnacht et al. 2012). Mitotane concentrations are associated with both efficacy and toxicity (Haak et al. 1994, Terzolo et al. 2000) and blood levels $\geq 14 \mathrm{mg} / \mathrm{l}$ predict ACC tumor response (Haak et al. 1994, Hermsen et al. 2011). A concentration range between 14 and $20 \mathrm{mg} / \mathrm{l}$ (corresponding to $44-62 \mu \mathrm{M}$ ) is considered as the ACC therapeutic window (Terzolo et al. 2000, Lee 2007, Hermsen et al. 2011), while lower doses of mitotane have been demonstrated to control hypercortisolism in the settings of CD (Baudry et al. 2012). The latter effect is usually ascribed to the adrenolytic action of mitotane, but a central inhibitory action on corticotrophs has never been investigated. We previously demonstrated that mitotane reduces both secretory activity and cell viability of pituitary TSH-secreting mouse cells (Zatelli et al. 2010), suggesting a possible direct effect on pituitary cells. Therefore, the aim of our study was to investigate whether mitotane may affect corticotroph function and cell survival in vitro.

\section{Materials and methods}

\section{Reagents}

Mitotane (Supelco, Bellefonte, PA, USA) was resuspended in absolute ethanol. Therefore, control cells have been incubated in culture medium containing $0.1 \%$ ethanol in all experiments. All reagents were purchased from Sigma if not otherwise indicated.

\section{Cell culture}

The mouse ACTH-secreting pituitary adenoma cell line, AtT20/D16v-F2, was obtained from the American Type Culture Collection (ATCC, Manassas, VA, USA). The cell line was maintained in DMEM (Invitrogen) supplemented with 10\% horse serum (HS) (LGC Standards, Milano, Italy) and antibiotic antimycotic (EuroClone, Milano, Italy) at $37^{\circ} \mathrm{C}$ in $5 \% \mathrm{CO}_{2}$, as described previously (Gentilin et al. 2013). Before each experiment, cells were incubated in $0.5 \% \mathrm{HS}$ medium for $48 \mathrm{~h}$ followed by a $24-\mathrm{h}$ incubation in $10 \%$ HS medium.

The human thyroid follicular epithelial cell line, Nthy-ori 3-1 (ECACC, Salisbury, UK), was maintained in RPMI-1640 medium (Invitrogen) supplemented with $10 \%$ fetal bovine serum (FBS) (LGC Standards) and antibiotic antimycotic (EuroClone) as described previously (Caselli et al. 2012).

The human endometrial stromal cell line, T-HESC (ATCC), was maintained in DMEM/F12 (Invitrogen) supplemented with $1.5 \mathrm{~g} / \mathrm{l}$ sodium bicarbonate, $1 \%$ ITS + Premix, $500 \mathrm{ng} / \mathrm{ml}$ puromycin, and 10\% charcoal/dextran-treated FBS (LGC Standards).

The human kidney cell line, 4/5 (generously provided by Dr Gianluca Aguiari, Department of Biomedical and Specialty Surgical Sciences, University of Ferrara), was maintained in DMEM (Invitrogen) supplemented with 10\% FBS (LGC Standards) and antibiotic antimycotic (EuroClone).

\section{Tissue collection and primary culture}

The liver sample was derived from a patient diagnosed with liver hyperplasia and operated on at the University of Ferrara (Section of Endocrinology and Institute of Surgery). The pituitary adenoma samples derived from five patients were operated on for ACTH-secreting pituitary adenomas at the Department of Neurosurgery, Ospedale Maggiore - Bellaria, Bologna, Italy. Tissues were collected following the guidelines of the local committee on human research and immediately minced in RPMI1640 medium (Invitrogen) under sterile conditions. Primary cultures were then prepared as described previously (Zatelli et al. 2006, Martínez-Fuentes et al. 2011). Informed consent of the patients was obtained for disclosing clinical investigation and performing the in vitro study.

\section{Viable cell number assessment}

Variations in cell number were assessed by the ATPlite assay (PerkinElmer, Waltham, MA, USA), as described previously (Zatelli et al. 2007). Briefly, the cells were seeded at $9 \times 10^{3}$ cells/well in 96-well white plates and then exposed to test substances. After incubation time, substrate solution was added directly to the cell culture plates

Published by Bioscientifica Ltd. 
at room temperature. The plates were shaken at 700 r.p.m. for $2 \mathrm{~min}$ and then measured for luminescent output (relative light units (RLU)) by Victor ${ }^{3} 1420$ Multilabel Counter (PerkinElmer). Results are expressed as mean value \pm s.E.M. percent cell viability vs vehicle-treated control cells in five independent experiments in six replicates.

\section{Caspase activity}

Caspase activity was measured using the Caspase-Glo 3/7 assay (Promega) following the manufacturer's instruction as described previously (Tagliati et al. 2010). Results are expressed as mean value \pm s.e.m. percent RLU vs vehicletreated control cells in five independent experiments in six replicates.

\section{ACTH secretion}

ACTH secretion was evaluated by measuring mouse ACTH immunoreactivity in the conditioned culture medium with the ACTH 'Ultra Sensitive' lumELISA kit (Calbiotech, Spring Valley, CA, USA). Hormone assays were performed in duplicate after appropriate sample dilutions. The sensitivity was $<1 \mathrm{pg} / \mathrm{ml}$ at the $95 \%$ confidence limit. Intra- and interassay CV were 6 and $8.7 \%$ respectively. The assay results were normalized by cell number, as determined from the ATPlite assay. Results are expressed as the mean value \pm s.E.M. percent ACTH concentration vs vehicle control cells in seven experiments in duplicate.

\section{Pomc gene expression}

Total RNA from treated cells was extracted with TRIzol reagent (Invitrogen) and treated with RNase-free DNase (Promega), as previously reported (Minoia et al. 2012). The Experion automated electrophoresis system (Bio-Rad) was used to determine the concentration and integrity of RNA samples. Only samples with RNA quality index $>9$ were reverse transcribed using the first-strand cDNA synthesis kit (Invitrogen) following the manufacturer's instructions.

Pomc expression evaluation was performed by relative quantitative real-time PCR (QRT-PCR). All QRT-PCRs were conducted with the TaqMan gene expression assay (Applied Biosystems), run on Applied Biosystems 7700 ABI Prism thermal cycler, and analyzed with the SDS 1.9 Software (Applied Biosystems). Glyceraldehyde 3-phosphate dehydrogenase was identified as the most stable reference gene from a set of five tested candidate housekeeping genes (Table 1) by the geNorm software, version 3.4 (Vandesompele et al. 2002). Relative expression ratio of Pomc mRNA (assay ID Mm00435874_m1; Applied Biosystems) was calculated by applying the method described by Pfaffl (2001). Results are expressed as mean value \pm s.E.m. percent Pomc expression vs vehicle-treated control cells from at least five independent experiments in five replicates.

\section{Statistical analysis}

Results were expressed as \pm s.E.M. and analyzed statistically using Student's $t$-tests to evaluate individual differences between means. Differences were considered significant at $P<0.05$.

\section{Results}

\section{Effects of mitotane on basal and corticotropin-releasing hormone-induced AtT20/D16v-F2 cell viability}

In order to determine the effects of mitotane on corticotroph cell viability, the latter was assessed in AtT20/D16vF2 after 6- and 24-h treatment without or with increasing mitotane concentrations $(10-100 \mu \mathrm{M}$, corresponding to plasma levels of 3.2-32 mg/l). As shown in Fig. 1A, after $6 \mathrm{~h}$, mitotane significantly reduced cell viability at $100 \mu \mathrm{M}$ $(-29 \% ; P<0.01)$; after $24 \mathrm{~h}$, mitotane significantly

Table 1 Primers and probe for candidate housekeeping genes

\begin{tabular}{|c|c|}
\hline Gene & Primers and probe \\
\hline Cyclophilin & $\begin{array}{l}\text { Primer reverse } 5^{\prime} \text {-AAACAGCTCGAAGGAGACGC-3' } \\
\text { Primer forward 5'-ACCGTGTTCTTCGACATCACG-3' } \\
\text { Probe } 5^{\prime}-6^{\prime} \text { FAM-ATGACGAGCCCTTGGG-MGB-3' }\end{array}$ \\
\hline Ribosomal L37 & $\begin{array}{l}\text { Primer reverse } 5^{\prime} \text {-CAGCTGCCCTCTTGGGTTT-3' } \\
\text { Primer forward } 5^{\prime} \text {-CCGCAGATTCAGACATGGATT-3' } \\
\text { Probe } 5^{\prime}-6^{\prime} \text { FAM-TGAGGGAACAACGCC-MGB-3' }\end{array}$ \\
\hline $\begin{array}{l}18 \mathrm{~S} \\
\text { Gadph }\end{array}$ & $\begin{array}{l}\text { 4319413E TaqMan endogenous control; Applied Biosystems } \\
\text { 4352339E TaqMan endogenous control; Applied Biosystems }\end{array}$ \\
\hline$\beta$-Actin & 4352341E TaqMan endogenous control; Applied Biosystems \\
\hline
\end{tabular}




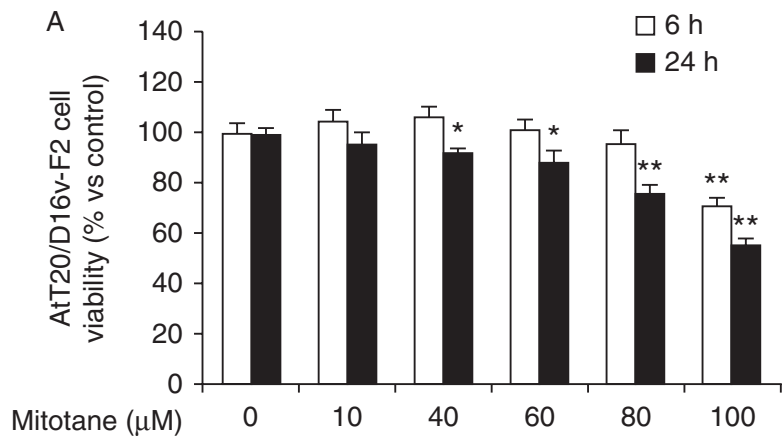

B
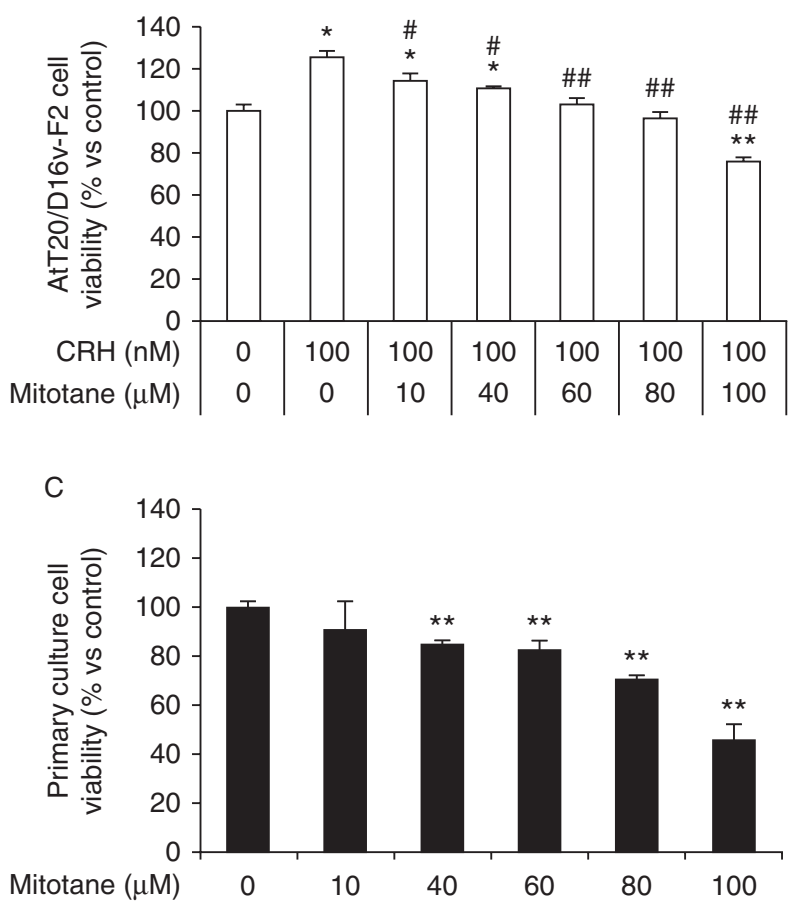

Figure 1

Effects of mitotane on mouse and human ACTH-secreting pituitary adenoma cell viability. (A) AtT20/D16v-F2 cells were incubated for 6 (white bars) and $24 \mathrm{~h}$ (black bars) with 10-100 $\mu \mathrm{M}$ mitotane; control cells were treated with vehicle solution. Cell viability was assessed in at least five independent experiments with six replicates each and is expressed as the mean value \pm S.E.M. percent cell viability vs vehicle control cells. ${ }^{*} P<0.05$ and $* * P<0.01$ vs vehicle control cells. (B) AtT20/D16v-F2 cells were incubated for $6 \mathrm{~h}$ with $10-100 \mu \mathrm{M}$ mitotane without or with $100 \mathrm{nM} \mathrm{CRH}$; control cells were treated with vehicle solution. Cell viability was assessed in at least five independent experiments with six replicates each and is expressed as the mean value \pm S.E.M. percent cell viability vs vehicle control cells. ${ }^{*} P<0.05$ and ${ }^{*} * P<0.01$ vs vehicle control cells. ${ }^{\#} P<0.05$ and ${ }^{\# \#} P<0.01$ vs $100 \mathrm{nM}$ CRH-treated cells. (C) Human ACTH-secreting pituitary adenoma primary cultures were incubated for $24 \mathrm{~h}$ with 10-100 $\mu \mathrm{M}$ mitotane; control cells were treated with vehicle solution. The graph represents the average of cell viability measurements of five primary cultures. Data were evaluated independently with six replicates each and were expressed as the mean value \pm s.E.M. percent cell viability vs vehicle control cells. $* * P<0.01$ vs vehicle control cells. reduced cell viability at concentrations $\geq 40 \mu \mathrm{M}$, from $8 \%$ $(P<0.05)$ to $45 \%$ vs control $(P<0.01)$.

Time-course experiments showed that treatment with $100 \mathrm{nM}$ corticotropin-releasing hormone (CRH) significantly induced cell viability after incubation up to $6 \mathrm{~h}$ by $\sim 20 \%(P<0.05$; data not shown). No effect was observed for longer incubation intervals. As the cells were incubated with CRH without any treatment renewal, we hypothesized that $\mathrm{CRH}$ will be degraded at long exposure time; therefore, experiments employing $\mathrm{CRH}$ were performed with a 6-h incubation time.

To investigate whether mitotane may influence CRHinduced AtT20/D16v-F2 cell viability, the latter was measured after a 6-h incubation with $\mathrm{CRH}$ alone or in combination with increasing mitotane concentrations $(10-100 \mu \mathrm{M})$. As shown in Fig. 1B, CRH induced a significant $(P<0.05)$ increase in AtT20/D16v-F2 cell viability $(+25 \%)$, which was significantly reduced by mitotane at all concentrations (from 12 to 50\% when compared with CRH-treated cells).

\section{Effects of mitotane on human ACTH-secreting pituitary adenoma cell viability}

In order to determine the effects of mitotane on human ACTH-secreting pituitary adenoma cell viability, the latter was assessed in human primary cultures from ACTHsecreting pituitary adenomas after 24-h treatment without or with increasing mitotane concentrations $(10-100 \mu \mathrm{M}$, corresponding to plasma levels of $3.2-32 \mathrm{mg} / \mathrm{l}$ ). As shown in Fig. 1C, after $24 \mathrm{~h}$, mitotane significantly reduced cell viability at concentrations $\geq 40 \mu \mathrm{M}$, from $15 \%(P<0.01)$ to $55 \%$ vs control $(P<0.01)$.

\section{Effects of mitotane on cell viability of thyroid, endometrial, renal, and liver cells}

In order to determine the specificity of mitotane effects, cell viability was assessed in NTHY-ori 3-1, T-HESC, $4 / 5$ cell lines, and in a liver primary culture after 24 -h treatment without or with increasing mitotane concentrations $(10-100 \mu \mathrm{M}$, corresponding to plasma levels of $3.2-32 \mathrm{mg} / \mathrm{l}$ ). As shown in Fig. 2, mitotane did not significantly modify the viability of any investigated cell line.

\section{Effects of mitotane on AtT20/D16v-F2 apoptosis and CRH influence}

To investigate whether mitotane reduces cell viability by activating apoptosis, caspase $3 / 7$ activity was measured in

Published by Bioscientifica Ltd 
AtT20/D16v-F2 cells incubated for 6 and $24 \mathrm{~h}$ in the presence of increasing mitotane concentrations $(10-100 \mu \mathrm{M})$. As shown in Fig. 3A, mitotane significantly induced apoptosis at $40-100 \mu \mathrm{M}$ after both $6 \mathrm{~h}$ (from 48 to $434 \% ; P<0.01)$ and $24 \mathrm{~h}$ (from +83 to $+763 \% ; P<0.01)$
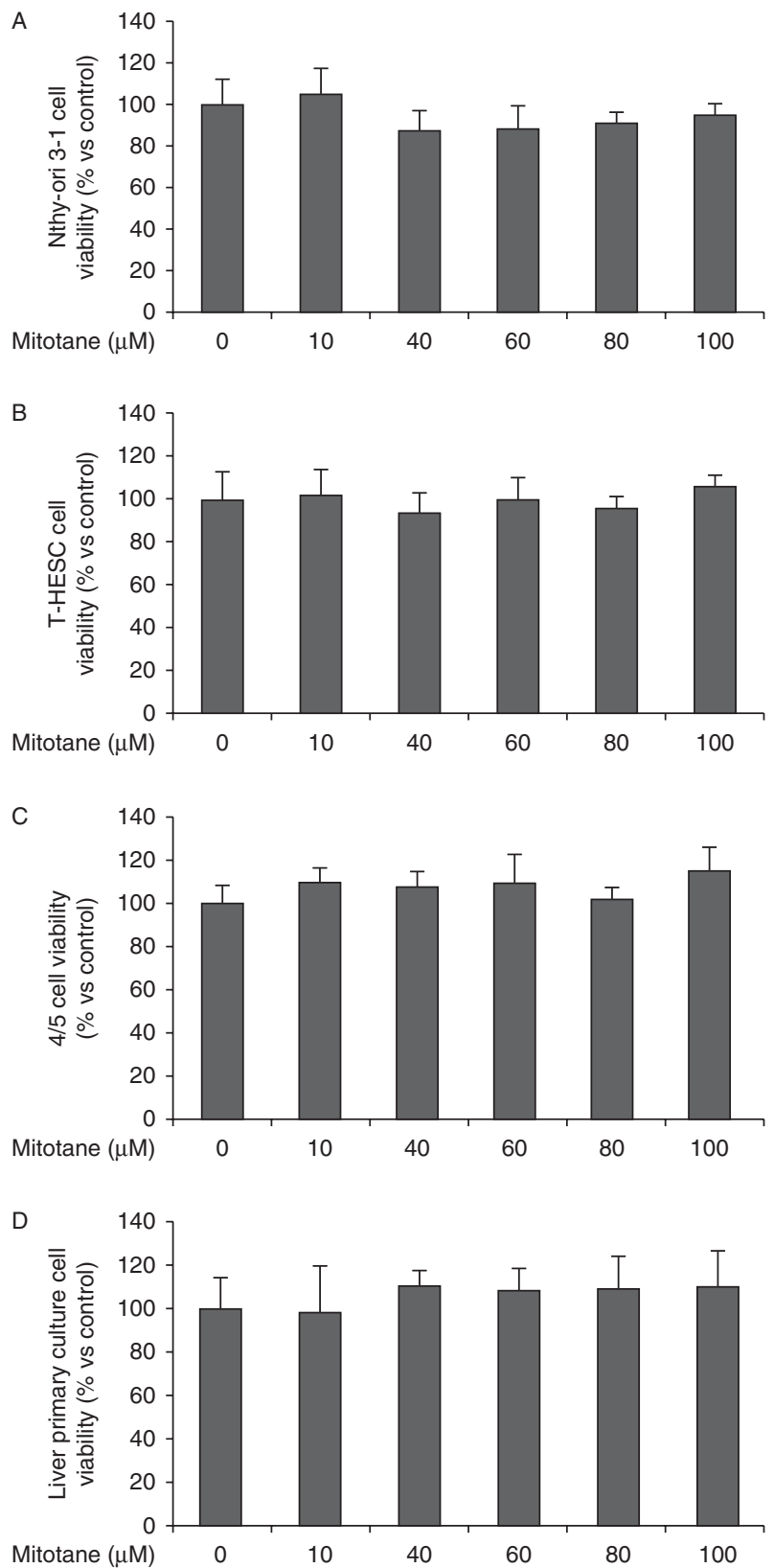

Figure 2

Effects of mitotane on cell viability of thyroid, endometrial, renal, and liver cells. Cells were incubated for $24 \mathrm{~h}$ with $10-100 \mu \mathrm{M}$ mitotane; control cells were treated with vehicle solution. Nthy-ori (A), T-HESC (B), and 4/5 (C) cell viability was assessed in at least five independent experiments with six replicates each. Liver primary culture cell viability (D) was assessed in six replicates. Cell viability was expressed as the mean value \pm s.E.M. percent cell viability vs vehicle control cells. when compared with vehicle-treated control cells. We observed that, after $6 \mathrm{~h}$, at concentrations $<100 \mu \mathrm{M}$ mitotane significantly induced caspase activation but did not affect cell viability, suggesting that a short exposure time does not compromise the viability of corticotroph cells but commits them to apoptosis.

To investigate the influence of $\mathrm{CRH}$ on mitotaneinduced apoptosis, caspase $3 / 7$ activity was measured in AtT20/D16v-F2 cells incubated for $6 \mathrm{~h}$ with CRH alone or in combination with increasing mitotane concentrations. As shown in Fig. 3B, CRH did not significantly affect basal caspase $3 / 7$ activity but completely blocked the proapoptotic effects of mitotane at $40 \mu \mathrm{M}$. However, the inhibitory effect of CRH on mitotane-induced caspase activation was lost partially at $60 \mu \mathrm{M}$ and completely at $100 \mu \mathrm{M}$ mitotane.

\section{Effects of mitotane on human ACTH-secreting pituitary adenoma primary culture apoptosis}

To investigate whether mitotane reduces cell viability in human ACTH-secreting pituitary adenoma primary cultures by activating apoptosis, caspase 3/7 activity was measured after incubation for $24 \mathrm{~h}$ in the presence of increasing mitotane concentrations $(10-100 \mu \mathrm{M})$. As shown in Fig. 3C, mitotane significantly induced apoptosis at $40-100 \mu \mathrm{M}$ (from +60 to $+620 \%$; $P<0.01$ ) when compared with vehicle-treated control cells.

\section{Effects of mitotane on basal ACTH secretion}

To determine the effects of mitotane on ACTH secretion, ACTH levels were assessed in conditioned medium from AtT20/D16v-F2 cells treated for 6 and $24 \mathrm{~h}$ with increasing mitotane concentrations $(10-100 \mu \mathrm{M})$. As shown in Fig. 4A, mitotane significantly reduced basal ACTH secretion after a 6-h treatment at both 80 and $100 \mu \mathrm{M}$ ( -65 and $-87 \%$ respectively; $P<0.01)$. After $24 \mathrm{~h}$, mitotane significantly reduced ACTH secretion at $\geq 60 \mu \mathrm{M}$ (from 40 to $96 \%$ ).

ACTH levels were also assessed in conditioned medium from human ACTH-secreting pituitary adenoma primary cultures treated for $24 \mathrm{~h}$ with increasing mitotane concentrations $(10-100 \mu \mathrm{M})$. As shown in Fig. 4B, mitotane significantly reduced basal ACTH secretion at $\geq 60 \mu \mathrm{M}$ (from 35 to $94 \% ; P<0.01$ ).

\section{Effects of mitotane on CRH-stimulated ACTH secretion}

To evaluate ACTH secretory response to $\mathrm{CRH}$ in vitro, AtT20/D16v-F2 cells were incubated for 0, 2, 5, 10, 15, and

Published by Bioscientifica Ltd 
30 min with $\mathrm{CRH}$ at $100 \mathrm{nM}$, a concentration at which $\mathrm{CRH}$ is known to induce ACTH secretion in these cells (Strowski et al. 2002). ACTH was then assayed in the condition medium. As shown in Fig. 5A, CRH significantly
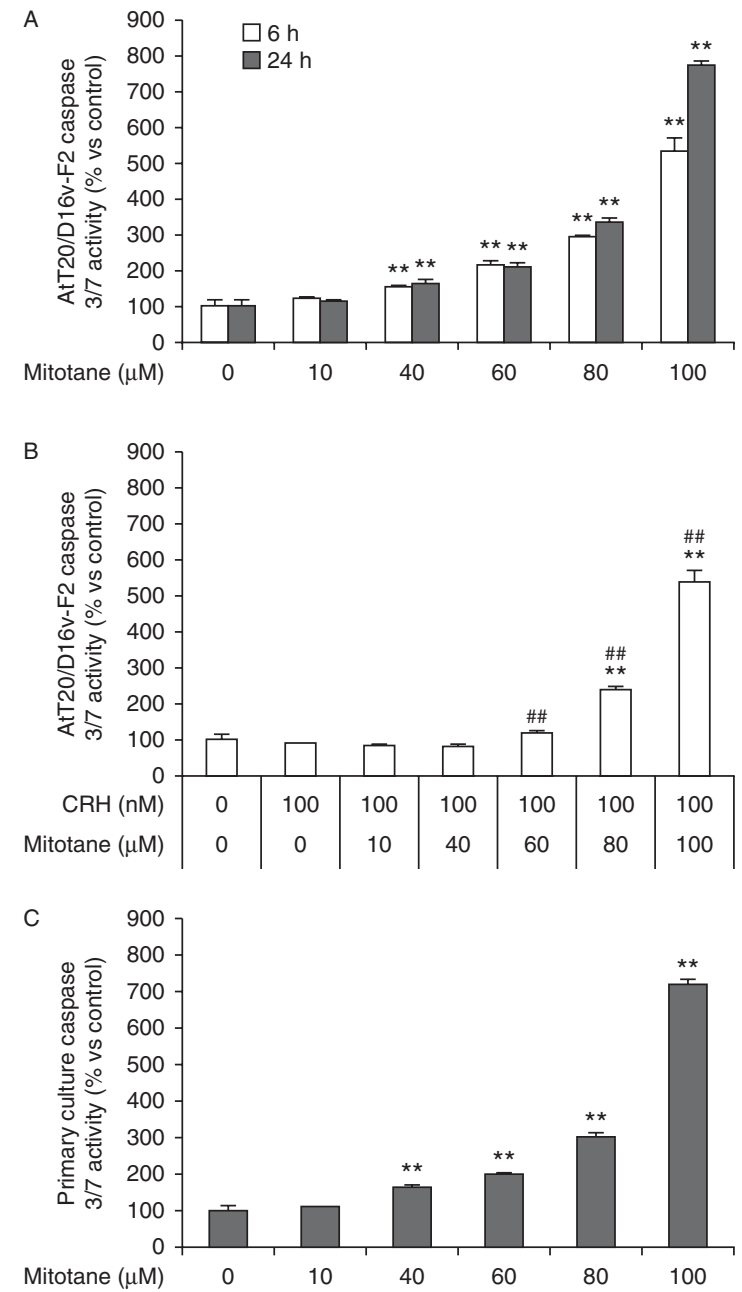

Figure 3

Effects of mitotane on caspase activity. (A) AtT20/D16v-F2 cells were incubated for 6 (white bars) and $24 \mathrm{~h}$ (gray bars) with 10-100 $\mu \mathrm{M}$ mitotane; control cells were treated with vehicle solution. Caspase 3/7 activity was measured in at least five independent experiments in six replicates and is expressed as percent mean value \pm s.E.M. caspase $3 / 7$ activity vs vehicletreated control cells. ${ }^{*} P<0.01$ vs vehicle-treated control cells.

(B) AtT20/D16v-F2 cells were treated for $6 \mathrm{~h}$ with 10-100 $\mu \mathrm{M}$ mitotane in the presence of $100 \mathrm{nM} \mathrm{CRH}$; control cells were treated with vehicle solution. Caspase 3/7 activity was measured in at least five independent experiments in six replicates and is expressed as percent mean value \pm S.E.M. caspase $3 / 7$ activity vs vehicle-treated control cells. ${ }^{*} P<0.01$ vs vehicletreated control cells. ${ }^{\# \#} P<0.01$ vs $100 \mathrm{nM}$ CRH-treated cells. (C) Human ACTH-secreting pituitary adenoma primary cultures were incubated for $24 \mathrm{~h}$ with $10-100 \mu \mathrm{M}$ mitotane; control cells were treated with vehicle solution. The graph represents the average of caspase 3/7 measurements of five primary cultures. Data were evaluated independently with six replicates each and were expressed as the mean value \pm S.E.M. percent cell viability vs vehicle control cells. ${ }^{*} P<0.01$ vs vehicle control cells.
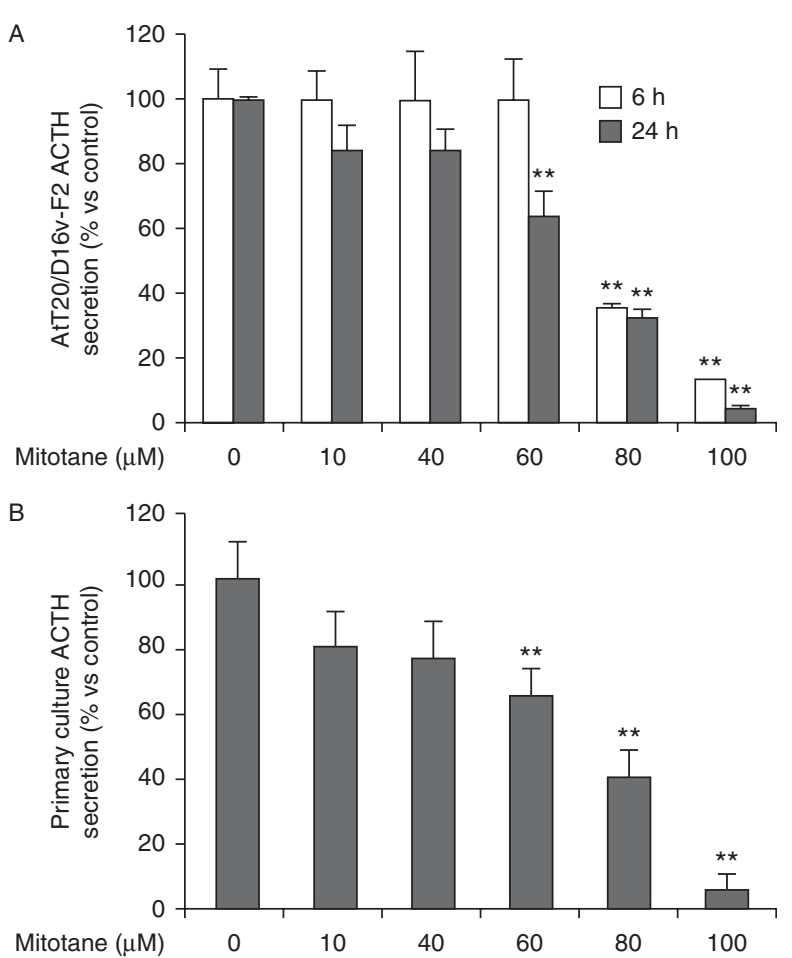

\section{Figure 4}

Effects of mitotane on ACTH secretion. (A) AtT20/D16v-F2 cells were incubated for 6 (white bars) and $24 \mathrm{~h}$ (gray bars) with 10-100 $\mu \mathrm{M}$ mitotane; control cells were treated with vehicle solution. ACTH levels were measured in conditioned medium by ELISA in seven independent experiments in duplicate and are expressed as the mean value \pm s.E.M. percent ACTH secretion vs vehicle control cells. ${ }^{*} P<0.01$ vs vehicle control cells.

(B) Human ACTH-secreting pituitary adenoma primary cultures were incubated for $24 \mathrm{~h}$ with $10-100 \mu \mathrm{M}$; control cells were treated with vehicle solution. ACTH levels were measured in conditioned medium by ELISA in independent experiments with six replicates each. The graph represents the average of ACTH measurements from five primary cultures. Data were expressed as the mean value \pm S.E.M. percent cell viability vs vehicle control cells. ${ }^{*} P<0.01$ vs vehicle control cells.

induced ACTH secretion up to $15 \mathrm{~min}$, reaching the peak value after $2 \min (+80 \% ; P<0.01$ vs time point 0$)$.

To determine whether mitotane affects CRH-induced ACTH secretion by AtT20/D16v-F2 cells, the cells were treated with $10-100 \mu \mathrm{M}$ mitotane for 6 and $24 \mathrm{~h}$. The medium was then removed and cells were stimulated with $100 \mathrm{nM}$ CRH or vehicle for $2 \mathrm{~min}$; then, ACTH concentration was evaluated. As shown in Fig. 5B, basal and CRHinduced ACTH secretion was higher after $6 \mathrm{~h}$ when compared with 24-h vehicle incubation. Pre-incubation for $6 \mathrm{~h}$ with mitotane at $\geq 40 \mu \mathrm{M}$ significantly reduced both basal and CRH-induced ACTH secretion, which was completely suppressed at $\geq 80 \mu \mathrm{M}$ mitotane. Pre-incubation for $24 \mathrm{~h}$ with mitotane at $\geq 10 \mu \mathrm{M}$ significantly reduced both basal and CRH-induced ACTH secretion, which was completely suppressed at $\geq 80 \mu \mathrm{M}$ mitotane.

Published by Bioscientifica Ltd. 
A

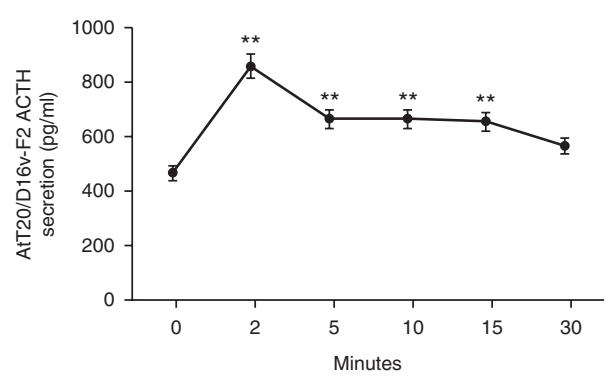

B

$\rightarrow-\mathrm{CRH}$ after $6 \mathrm{~h}$ mitotane treatment
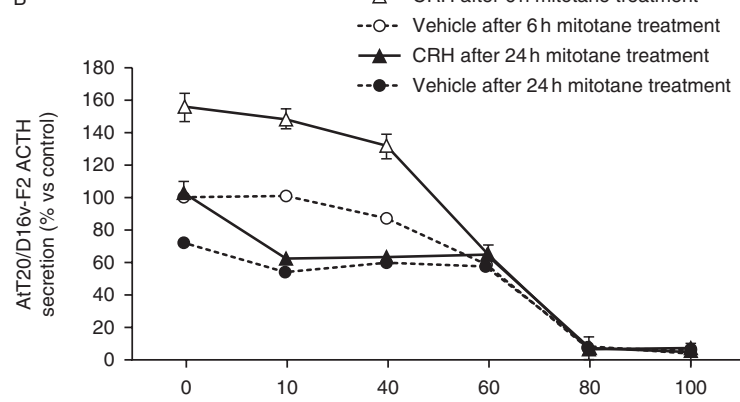

Mitotane $(\mu \mathrm{M})$

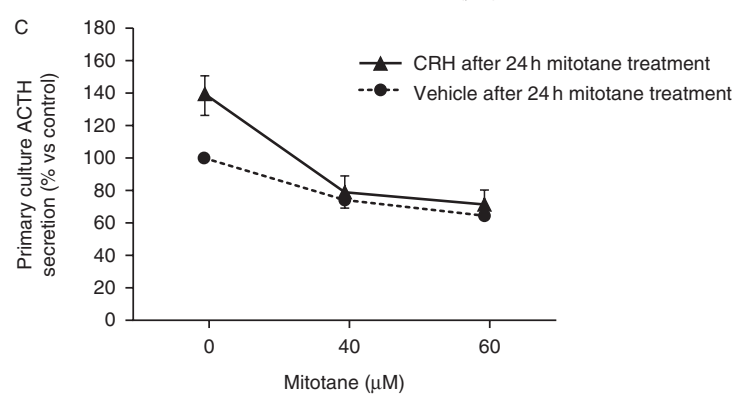

Figure 5

Effects of mitotane on CRH-induced ACTH secretion. (A) AtT20/D16v-F2 cells were incubated for $0,2,5,10,15$, and $30 \mathrm{~min}$ with $100 \mathrm{nM} \mathrm{CRH}$. Medium was collected and ACTH concentration was assessed by ELISA. Data were evaluated independently in at least seven experiments in duplicate and are expressed as the mean value \pm s.E.M. $\mathrm{pg} / \mathrm{ml}$. $* \star P<0.01$ vs vehicle control cells. (B) AtT20/D16v-F2 cells were incubated for 6 and $24 \mathrm{~h}$ in culture medium supplemented with 10-100 $\mu \mathrm{M}$ mitotane and then stimulated with $100 \mathrm{nM} \mathrm{CRH}$ or vehicle for $2 \mathrm{~min}$. $0=$ vehicle control cells treated with $\mathrm{CRH}$ or vehicle for $2 \mathrm{~min}$. Data were evaluated independently in seven experiments in duplicate and are expressed as the mean value \pm S.E.M. percent ACTH secretion vs vehicle control cells. (C) Human ACTH-secreting pituitary adenoma primary cultures were incubated for $24 \mathrm{~h}$ in culture medium supplemented with 40-60 $\mu \mathrm{M}$ mitotane and then stimulated with $100 \mathrm{nM}$ CRH or vehicle. The graph represents the average of ACTH secretion measurements of five primary cultures. Data were evaluated independently with six replicates each and were expressed as the mean value \pm s.E.M. percent ACTH secretion vs vehicle control cells.

To determine whether mitotane affects CRH-induced ACTH secretion by human ACTH-secreting pituitary adenoma primary cultures, the cells were treated with 40-60 $\mu \mathrm{M}$ mitotane for $24 \mathrm{~h}$ and then stimulated with $100 \mathrm{nM} \mathrm{CRH}$ or vehicle for $2 \mathrm{~min}$; then, ACTH concentration was evaluated. As shown in Fig. 5C, CRH induced ACTH secretion by primary cultured cells $(+40 \%$; $P<0.01)$; pre-incubation with mitotane at $40-60 \mu \mathrm{M}$ significantly $(P<0.01)$ reduced both basal and CRH-induced ACTH secretion.

\section{Effects of mitotane on Pomc mRNA expression and CRH influence}

To determine the effects of mitotane on Pomc mRNA expression, Pomc mRNA levels were assessed in AtT20/ D16v-F2 cells treated for $6 \mathrm{~h}$ with $10-100 \mu \mathrm{M}$ mitotane. As shown in Fig. 6, mitotane significantly $(P<0.01)$ reduced basal Pomc mRNA expression by $\sim 70 \%$ at all concentrations tested. On the contrary, $100 \mathrm{nM}$ CRH significantly $(P<0.01)$ induced Pomc mRNA expression $(+100 \%$ vs vehicle control cells), an effect completely counteracted by mitotane at all concentrations tested.

\section{Discussion}

Our study provides for the first time evidence that mitotane has a direct and important action on human ACTH-secreting pituitary adenoma primary cultures and on the AtT20/D16v-F2 cell line, whose function may be greatly and quickly compromised. This inhibitory effect is, at least in part, due to direct inhibition of corticotroph cell viability, which is reduced by mitotane already after $6 \mathrm{~h}$ at high doses in AtT20/D16v-F2 cells and after $24 \mathrm{~h}$ at the

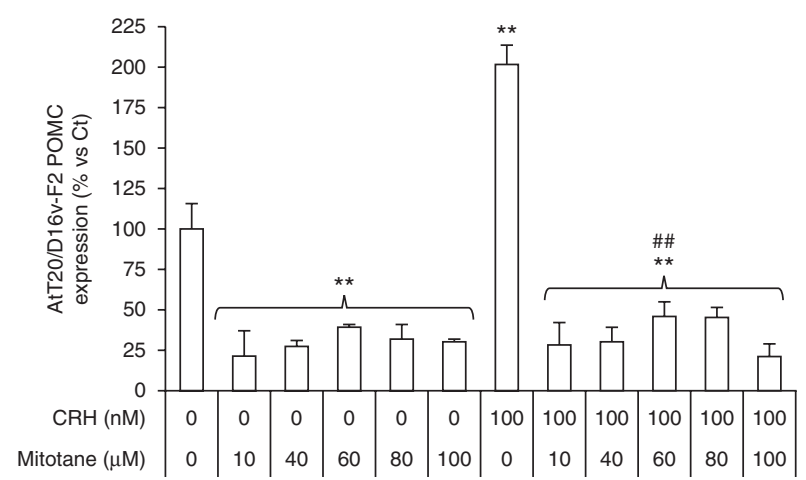

Figure 6

Effects of mitotane on Pomc expression. AtT20/D16v-F2 cells were treated for $6 \mathrm{~h}$ without or with 10-100 $\mu \mathrm{M}$ mitotane in the presence or in the absence of $100 \mathrm{nM} \mathrm{CRH}$; control cells were treated with vehicle solution. Pomc expression was assessed by QRT-PCR. Results are expressed as mean value \pm S.E.M. percent Pomc expression vs vehicle-treated control cells from at least five independent experiments in five replicates. ${ }^{*} P<0.01$ vs vehicle control cells. ${ }^{\#} P<0.01$ vs cells treated with $100 \mathrm{nM} \mathrm{CRH}$.

Published by Bioscientifica Ltd. 
concentrations corresponding to the ACC therapeutic window in both mouse and human corticotroph cells. These data indicate that exposure time may have a differential impact on corticotroph viability, in agreement with a previous report indicating that mitotane reduces cell viability of a TSH-secreting pituitary cell line in a similar fashion (Zatelli et al. 2010). In addition, the evidence that caspase activation precedes cell viability reduction after mitotane treatment, supports the hypothesis that mitotane rapidly commits corticotroph cells to apoptosis which, in turn, after a long exposure time, results in cell viability reduction. On the other hand, mitotane does not affect cell viability of the endocrine cell line NTHY-ori 3-1, indicating that mitotane cytotoxic effects are not generalized to endocrine cells. Moreover, the viability of non-endocrine cells, such as T-HESC and $4 / 5$ cell lines and liver primary culture, is not influenced by the drug, supporting the hypothesis that mitotane acts rapidly with a specific effect at the pituitary level.

Previous clinical reports showed that in CD patients, mitotane, owing to its adrenolytic action, is highly effective in the long-term suppression of hypercortisolism (Luton et al. 1979, Schteingart et al. 1980), at concentrations lower that those employed for ACC treatment (Gross et al. 2007, Murao et al. 2010, Baudry et al. 2012), but central inhibitory actions have been overlooked.

Recently, Baudry et al. (2012) reported that in $24.5 \%$ of CD patients treated with mitotane as first-line treatment and with initial negative magnetic resonance imaging, a pituitary adenoma became apparent during or at the end of the treatment. These results may be explained by the anti-cortisolic effects exerted by mitotane at the doses employed in this study, corresponding to $\sim 20-30 \mu \mathrm{M}$, which are approximately twofold lower than those employed in our experiments. Indeed, in their hands, mitotane significantly lowered cortisol levels in the majority of patients, with a consequent disappearance of negative feedback at the pituitary level. The latter allowed the increase in ACTH plasma levels and the visualization of a pituitary adenoma in 12 patients (Baudry et al. 2012), similar to what happens in Nelson's syndrome. Of these patients, ten had been operated on, but the authors do not disclose pathological characteristics of the adenomas, such as ki-67 (Fusco et al. 2008), which may be helpful in understanding the direct effects of mitotane at pituitary level. By contrast, in our experimental settings, we observed a reduction in corticotroph function and cell viability at higher mitotane concentrations $(\geq 40 \mu \mathrm{M})$, suggesting that direct pituitary effects may become apparent only in the presence of drug concentrations in the ACC therapeutic window. This hypothesis is further strengthened by the evidence that, upon (low-dose) mitotane withdrawal, $\sim 70 \%$ of patients showed recurrence of hypercortisolism (Baudry et al. 2012), suggesting a lack of central effect when mitotane plasma level is $<40 \mu \mathrm{M}$. Our data show that higher mitotane doses impair corticotroph function and viability and therefore might be effective in controlling the disease at the pituitary level and in preventing recurrence after withdrawal. Clinical studies are necessary to clarify this issue.

The hypophysiotropic hormone CRH (Florio et al. 2007) has been previously demonstrated to significantly stimulate AtT20/D16v cell proliferation (van Wijk et al. 1995). Our results show that CRH induces cell viability only in the short term, suggesting a protective rather than a proliferative effect of this peptide on corticotroph cells. In keeping with our results, Lezoualc'h et al. (2000) indicated $\mathrm{CRH}$ as an endogenous protective neuropeptide against oxidative cell death in addition to its function in the HPA system. In addition, our data show that mitotane dose dependently reduced the stimulatory effects of $\mathrm{CRH}$ on mouse corticotroph cell viability. These data suggest that ACTH-secreting cells may become refractory to physiological stimuli, such as $\mathrm{CRH}$, after exposure to mitotane. Moreover, we observed that the inhibitory effects of mitotane on human and mouse ACTH-secreting pituitary adenoma cell viability are, at least in part, due to apoptosis induction, as previously reported in other experimental models (Pushkarev et al. 2007, Zatelli et al. 2010). In our settings, caspase activation is prompted quickly and persists for at least $24 \mathrm{~h}$. We also observed that, after $6 \mathrm{~h}$, at concentrations $<100 \mu \mathrm{M}$, mitotane significantly induced caspase activation but did not affect cell viability, suggesting that a very short exposure time does not compromise the viability of corticotroph cells but commits them to apoptosis.

As already noted, mitotane, at concentrations lower than those reached in vivo, is able to reduce steroids and TSH secretion in adrenocortical and pituitary TSHsecreting cell lines respectively (Stigliano et al. 2008, Zatelli et al. 2010). Our findings support the evidence that mitotane affects pituitary function, also reducing the secretory activity of corticotroph cells. Mitotane inhibits ACTH secretion at high concentrations $(80-100 \mu \mathrm{M})$ after $6 \mathrm{~h}$ of incubation in AtT20/D16v-F2 cells and at $\geq 60 \mu \mathrm{M}$ after $24 \mathrm{~h}$ of exposure in human and mouse ACTHsecreting pituitary adenoma cells. This indicates, as previously suggested, that mitotane has a toxic effect on corticotroph function, providing further support to the use of this drug for persistent and refractory CD (Kawai

Published by Bioscientifica Ltd 
et al. 1999, Baudry et al. 2012). A recent study reported that plasma mitotane concentrations $>8.5 \mathrm{mg} / 1$ (corresponding to $24 \mu \mathrm{M}$ ) are sufficient to achieve CD control (Baudry et al. 2012). On the contrary, in our settings, mitotane reduced ACTH secretion at a concentration of $60 \mu \mathrm{M}$, suggesting that a greater exposure time may be needed to affect pituitary hormonal secretion.

In patients treated with adjuvant mitotane following complete ACC removal, ACTH levels are often nonsignificantly increased as it should be expected by mitotane-induced inhibition of adrenal steroidogenesis (Daffara et al. 2008). Furthermore, both Takamatsu et al. (1981) and Kawai et al. (1999) suggested that mitotane had an effect on corticotrophs, reporting that mitotane maintenance therapy may be a good treatment option for persistent and intractable CD. These findings support the hypothesis that mitotane impairs ACTH secretion and has a direct action on corticotroph cells when employed at high concentrations (i.e. those used for ACC).

Our results also show that AtT20/D16v-F2 cells respond to $\mathrm{CRH}$ stimulation with a rapid and significant increase in ACTH secretion. The stimulatory effect of CRH, however, is completely blunted by concentrations of mitotane $\geq 40 \mu \mathrm{M}$ after $6 \mathrm{~h}$ of exposure and at lower concentrations after $24 \mathrm{~h}$. These data indicate that mitotane rapidly affects the capability of adrenocorticotroph cells to respond to physiological stimuli, in keeping with the results obtained on cell viability. The antisecretory effects of mitotane on corticotroph cells are further supported by data from primary cultures, wherein CRH stimulatory effect is completely abolished by mitotane at the concentrations corresponding to the ACC therapeutic window. These results are in line with evidence that mitotane strongly inhibits TRH-induced TSH secretion, supporting the hypothesis that this drug acts rapidly and profoundly with a generalized effect at the pituitary level. This hypothesis is further strengthened by evidence that, after $6 \mathrm{~h}$, mitotane reduces Pomc expression independently of the concentration and regardless of CRH stimulation. Indeed, in keeping with the report by Aoki et al. (1997), CRH significantly induces Pomc expression, but, in our hands, it is not capable of rescuing cell function from mitotane toxic effects. Our data indicate that the effects of mitotane on ACTH secretion are not completely dependent on the effects on Pomc expression. Incubation with mitotane reduces shortterm ACTH spontaneous release, suggesting that mitotane, besides affecting Pomc gene transcription, may impair ACTH release, also influencing secretory mechanisms.
In conclusion, our results demonstrate that mitotane reduces cell viability and function of mouse and human pituitary ACTH-secreting adenoma cells, suggesting a direct pituitary effect of mitotane. In addition, we provide evidence for a higher sensitivity of corticotroph cells to mitotane, as other cell lines originating from tissues different from pituitary (and also of non-endocrine lineage) are not sensitive to the inhibitory effects of mitotane during short-time exposure.

However, the promising in vitro data showing efficacy of mitotane in CD at the doses used for ACC within $24 \mathrm{~h}$ must be confirmed in vivo for a longer period of time in clinical trials, balancing the efficacy of ACTH secretion reduction with the development of side effects.

\section{Declaration of interest}

The authors declare that there is no conflict of interest that could be perceived as prejudicing the impartiality of the research reported. The NIH statement does not apply.

\section{Funding}

This work was supported by grants from the Italian Ministry of Education, Research and University (FIRB RBAP11884M, RBAP1153LS, 2010TYCL9B_002), Fondazione Cassa di Risparmio di Ferrara, and Associazione Italiana per la Ricerca sul Cancro (AIRC) in collaboration with Laboratorio in rete del Tecnopolo 'Tecnologie delle terapie avanzate' (LTTA) of the University of Ferrara.

\section{Acknowledgements}

The authors thank Dr Giorgio Frank (Department of Neurosurgery, Ospedale Maggiore - Bellaria, Bologna, Italy) for his continuous support to our research in the pituitary field.

\section{References}

Aoki Y, Iwasaki Y, Katahira M, Oiso Y \& Saito H 1997 Regulation of the rat proopiomelanocortin gene expression in AtT-20 cells. I: effects of the common secretagogues. Endocrinology 138 1923-1929. (doi:10.1210/ en.138.5.1923)

Atkinson AB, Kennedy A, Wiggam MI, McCance DR \& Sheridan B 2005 Long-term remission rates after pituitary surgery for Cushing's disease: the need for long-term surveillance. Clinical Endocrinology 63 549-559. (doi:10.1111/j.1365-2265.2005.02380.x)

Baudry C, Coste J, Bou Khalil R, Silvera S, Guignat L, Guibourdenche J, Abbas H, Legmann P, Bertagna X \& Bertherat J 2012 Efficiency and tolerance of mitotane in Cushing's disease in 76 patients from a single center. European Journal of Endocrinology 167 473-481. (doi:10.1530/ EJE-12-0358)

Bergenstal DM, Hertz R, Lipsett MB \& Moy RH 1960 Chemiotherapy of adrenocortical cancer with $o, p^{\prime}$ DDD. Annals of Internal Medicine 53672. (doi:10.7326/0003-4819-53-4-672)

Biller BM, Grossman AB, Stewart PM, Melmed S, Bertagna X, Bertherat J, Buchfelder M, Colao A, Hermus AR, Hofland LJ et al. 2008 Treatment of adrenocorticotropin-dependent Cushing's syndrome: a consensus

Published by Bioscientifica Ltd. 
statement. Journal of Clinical Endocrinology and Metabolism 93 2454-2462. (doi:10.1210/jc.2007-2734)

Caselli E, Zatelli MC, Rizzo R, Benedetti S, Martorelli D, Trasforini G, Cassai E, degli Uberti EC, Di Luca D \& Dolcetti R 2012 Virologic and immunologic evidence supporting an association between HHV-6 and Hashimoto's thyroiditis. PLoS Pathogens 8 e1002951. (doi:10.1371/ journal.ppat.1002951)

Daffara F, De Francia S, Reimondo G, Zaggia B, Aroasio E, Porpiglia F, Volante M, Termine A, Di Carlo F, Dogliotti L et al. 2008 Prospective evaluation of mitotane toxicity in adrenalcortical cancer patients treated adjuvantly. Endocrine-Related Cancer 15 1043-1053. (doi:10.1677/ERC-08-0103)

Fassnacht M, Terzolo M, Allolio B, Baudin E, Haak H, Berruti A, Welin S, Schade-Brittinger C, Lacroix A, Jarzab B et al. 2012 Combination chemotherapy in advanced adrenocortical carcinoma. New England Journal of Medicine 366 2189-2197. (doi:10.1056/NEJMoa1200966)

Feelders RA, de Bruin C, Pereira AM, Romijn JA, Netea-Maier RT, Hermus AR, Zelissen PM, van Heerebeek R, de Jong FH, van der Lely AJ et al. 2010 Pasireotide alone or with cabergoline and ketoconazole in Cushing's disease. New England Journal of Medicine 362 1846-1848. (doi:10.1056/NEJMc1000094)

Florio P, Zatelli MC, Reis FM, degli Uberti EC \& Petraglia F 2007 Corticotropin releasing hormone: a diagnostic marker for behavioral and reproductive disorders? Frontiers in Biosciences 12 551-560. (doi:10.2741/2081)

Fusco A, Zatelli MC, Bianchi A, Cimino V, Tilaro L, Veltri F, Angelini F, Lauriola L, Vellone V, Doglietto F et al. 2008 Prognostic significance of the Ki-67 labeling index in growth hormone-secreting pituitary adenomas. Journal of Clinical Endocrinology and Metabolism 93 2746-2750. (doi:10.1210/jc.2008-0126)

Gentilin E, Tagliati F, Filieri C, Molè D, Minoia M, Rosaria Ambrosio M, Degli Uberti EC \& Zatelli MC 2013 miR-26a plays an important role in cell cycle regulation in ACTH-secreting pituitary adenomas by modulating protein kinase C $\delta$. Endocrinology 154 1690-1700. (doi:10.1210/en.2012-2070)

Gross BA, Mindea SA, Pick AJ, Chandler JP \& Batjer HH 2007 Medical management of Cushing's disease. Neurosurgery Focus 23 E10. (doi:10.3171/FOC-07/09/E10)

Haak HR, Hermans J, van de Velde CJ, Lentjes EG, Goslings BM, Fleuren GJ \& Krans HM 1994 Optimal treatment of adrenocortical carcinoma with mitotane: results in a consecutive series of 96 patients. British Journal of Cancer 69 947-951. (doi:10.1038/bjc.1994.183)

Hermsen IG, Fassnacht M, Terzolo M, Houterman S, den Hartigh J, Leboulleux S, Daffara F, Berruti A, Chadarevian R, Schlumberger M et al. 2011 Plasma concentrations of $o, p^{\prime} \mathrm{DDD}, o, p^{\prime} \mathrm{DDA}$, and $o, p^{\prime} \mathrm{DDE}$ as predictors of tumor response to mitotane in adrenocortical carcinoma: results of a retrospective ENS@T multicenter study. Journal of Clinical Endocrinology and Metabolism 96 1844-1851. (doi:10.1210/jc.2010-2676)

Hogan TF, Citrin DL, Johnson BM, Nakamura S, Davis TE \& Borden EC 1978 $o, p^{\prime}$-DDD (mitotane) therapy of adrenal cortical carcinoma: observations on drug dosage, toxicity, and steroid replacement. Cancer $\mathbf{4 2}$ 2177-2181. (doi:10.1002/1097-0142(197811)42:5<2177::AIDCNCR2820420514>3.0.CO;2-X)

Kawai S, Ichikawa Y, Kaburaki J \& Yoshida T 199918 years mitotane therapy for intractable Cushing's disease. Lancet 354 951. (doi:10.1016/ S0140-6736(05)75699-3)

Lee JE 2007 Adjuvant mitotane in adrenocortical carcinoma. New England Journal of Medicine 357 1256-1258. (doi:10.1056/NEJMc076267)

Lezoualc'h F, Engert S, Berning B \& Behl C 2000 CRH-mediated neuroprotection against oxidative stress is associated with the increased release of non-amyloidogenic amyloid beta precursor protein and with the suppression of nuclear factor-kappaB. Molecular Endocrinology 14 147-159. (doi:10.1210/me.14.1.147)

Lughezzani G, Sun M, Perrotte P, Jeldres C, Alasker A, Isbarn H, Budäus L, Shariat SF, Guazzoni G, Montorsi F et al. 2010 The European Network for the Study of Adrenal Tumors staging system is prognostically

http://joe.endocrinology-journals.org DOI: $10.1530 / J O E-13-0210$
(C) 2013 Society for Endocrinology Printed in Great Britain superior to the international union against cancer-staging system: a North American validation. European Journal of Cancer 46 713-719. (doi:10.1016/j.ejca.2009.12.007)

Luton JP, Mahoudeau JA, Bouchard P, Thieblot P, Hautecouverture M, Simon D, Laudat MH, Touitou Y \& Bricaire H 1979 Treatment of Cushing's disease by $o, p^{\prime}$ DDD: survey of 62 cases. New England Journal of Medicine 300 459-464. (doi:10.1056/ NEJM197903013000903)

Mahmoud-Ahmed AS \& Suh JH 2002 Radiation therapy for Cushing's disease: a review. Pituitary 5 175-180. (doi:10.1023/A:1023365200437)

Martínez-Fuentes AJ, Molina M, Vázquez-Martínez R, Gahete MD, Jiménez-Reina L, Moreno-Fernández J, Benito-López P, Quintero A, de la Riva A, Diéguez C et al. 2011 Expression of functional KISS1 and KISS1R system is altered in human pituitary adenomas: evidence for apoptotic action of kisspeptin-10. European Journal of Endocrinology 164 355-362. (doi:10.1530/EJE-10-0905)

Minoia M, Gentilin E, Molè D, Rossi M, Filieri C, Tagliati F, Baroni A, Ambrosio MR, degli Uberti E \& Zatelli MC 2012 Growth hormone receptor blockade inhibits growth hormone-induced chemoresistance by restoring cytotoxic-induced apoptosis in breast cancer cells independently of estrogen receptor expression. Journal of Clinical Endocrinology and Metabolism 97 E907-EE16. (doi:10.1210/jc.2011-3340)

Murao K, Imachi H, Ishida T, Hosomi N \& Masugata H 2010 Successful therapy of Cushing's disease caused by an extrapituitary parasellar adenoma. Clinical Endocrinology 73 133-134. (doi:10.1111/j.1365-2265. 2009.03763.x)

Patil CG, Prevedello DM, Lad SP, Vance ML, Thorner MO, Katznelson L \& Laws ER Jr 2008 Late recurrences of Cushing's disease after initial successful transsphenoidal surgery. Journal of Clinical Endocrinology and Metabolism 93 358-362. (doi:10.1210/jc.2007-2013)

Pfaffl MW 2001 A new mathematical model for relative quantification in real-time RT-PCR. Nucleic Acids Research 29 e45. (doi:10.1093/nar/ 29.9.e45)

Porpiglia F, Fiori C, Bovio S, Destefanis P, Alì A, Terrone C, Fontana D, Scarpa RM, Tempia A \& Terzolo M 2004 Bilateral adrenalectomy for Cushing's syndrome: a comparison between laparoscopy and open surgery. Journal of Endocrinological Investigation 27 654-658.

Pushkarev VM, Tronko ND, Kostyuchenko NN \& Mikosha AS 2007 Effect of $o, p^{\prime}$-DDD and $\mathrm{Li}+$ on apoptotic DNA fragmentation in conventionally normal and tumour tissues of human adrenal cortex. Ukrainskii Biokhimicheskii zhurnal 79 44-49.

Schteingart DE, Tsao HS, Taylor CI, McKenzie A, Victoria R \& Therrien BA 1980 Sustained remission of Cushing's disease with mitotane and pituitary irradiation. Annals of Internal Medicine 92 613-619. (doi:10.7326/0003-4819-92-5-613)

Stigliano A, Cerquetti L, Borro M, Gentile G, Bucci B, Misiti S, Piergrossi P, Brunetti E, Simmaco M \& Toscano V 2008 Modulation of proteomic profile in $\mathrm{H} 295 \mathrm{R}$ adrenocortical cell line induced by mitotane. Endocrine-Related Cancer 15 1-10. (doi:10.1677/ERC-07-0003)

Strowski MZ, Dashkevicz MP, Parmar RM, Wilkinson H, Kohler M, Schaeffer JM \& Blake AD 2002 Somatostatin receptor subtypes 2 and 5 inhibit corticotropin-releasing hormone-stimulated adrenocorticotropin secretion from AtT-20 cells. Neuroendocrinology 75 339-346. (doi:10.1159/000059430)

Tagliati F, Gentilin E, Buratto M, Molè D, degli Uberti EC \& Zatelli MC 2010 Magmas, a gene newly identified as overexpressed in human and mouse ACTH-secreting pituitary adenomas, protects pituitary cells from apoptotic stimuli. Endocrinology 151 4635-4642. (doi:10.1210/en. 2010-0441)

Takamatsu J, Kitazawa A, Nakata K, Furukawa K \& Nakai Y 1981 Does mitotane reduce endogenous ACTH secretion? New England Journal of Medicine 305 957. (doi:10.1056/NEJM198110153051618)

Terzolo M, Pia A, Berruti A, Osella G, Alì A, Carbone V, Testa E, Dogliotti L $\&$ Angeli A 2000 Low-dose monitored mitotane treatment achieves the therapeutic range with manageable side effects in patients with 
adrenocortical cancer. Journal of Clinical Endocrinology and Metabolism 85 2234-2238. (doi:10.1210/jc.85.6.2234)

Tritos NA \& Biller BM 2012 Advances in medical therapies for Cushing's syndrome. Discovery Medicine 13 171-179.

Vandesompele J, De Preter K, Pattyn F, Poppe B, Van Roy N, De Paepe A \& Speleman F 2002 Accurate normalization of real-time quantitative RT-PCR data by geometric averaging of multiple internal control genes. Genome Biology 3 RESEARCH0034. (doi:10.1186/gb-2002-3-7research0034)

van Wijk PA, van Neck JW, Rijnberk A, Croughs RJ \& Mol JA 1995 Proliferation of the murine corticotropic tumour cell line AtT20 is affected by hypophysiotrophic hormones, growth factors and glucocorticoids. Molecular and Cellular Endocrinology 111 13-19. (doi:10.1016/0303-7207(95)03541-E)

Young RB, Bryson MJ, Sweat ML \& Street JC 1973 Complexing of DDT and $o, p^{\prime}$ DDD with adrenal cytochrome P-450 hydroxylating systems. Journal of Steroid Biochemistry 4 585-591. (doi:10.1016/00224731(73)90033-2)
Zatelli MC, Piccin D, Tagliati F, Bottoni A, Luchin A, Vignali C, Margutti A, Bondanelli M, Pansini GC, Pelizzo MR et al. 2006 Selective activation of somatostatin receptor subtypes differentially modulates secretion and viability in human medullary thyroid carcinoma primary cultures: potential clinical perspectives. Journal of Clinical Endocrinology and Metabolism 91 2218-2224. (doi:10.1210/ jc.2006-0334)

Zatelli MC, Piccin D, Vignali C, Tagliati F, Ambrosio MR, Bondanelli M, Cimino V, Bianchi A, Schmid HA, Scanarini M et al. 2007 Pasireotide, a multiple somatostatin receptor subtypes ligand, reduces cell viability in non-functioning pituitary adenomas by inhibiting vascular endothelial growth factor secretion. Endocrine-Related Cancer 14 91-102. (doi:10.1677/ERC-06-0026)

Zatelli MC, Gentilin E, Daffara F, Tagliati F, Reimondo G, Carandina G, Ambrosio MR, Terzolo M \& degli Uberti EC 2010 Therapeutic concentrations of mitotane $\left(o, p^{\prime}\right.$-DDD) inhibit thyrotroph cell viability and TSH expression and secretion in mouse cell line model. Endocrinology 151 2453-2461. (doi:10.1210/en.2009-1404)

Received in final form 21 June 2013

Accepted 28 June 2013

Accepted Preprint published online 28 June 2013 